Article

\title{
Intrinsic Value and Perceived Essentialism of Culture Heritage Sites as Tools for Planning Interventions
}

\author{
Magdalena Roszczynska-Kurasinska ${ }^{1, * \mathbb{D}}$, Anna Domaradzka ${ }^{1} \mathbb{D}$, Anna Wnuk ${ }^{1}$ and Tomasz Oleksy $^{2}$ \\ 1 Robert Zajonc Institute for Social Studies, University of Warsaw, 00-183 Warszawa, Poland; \\ anna.domaradzka@uw.edu.pl (A.D.); anna.wnuk@psych.uw.edu.pl (A.W.) \\ 2 Faculty of Psychology, University of Warsaw, 00-183 Warszawa, Poland; tomasz.oleksy@psych.uw.edu.pl \\ * Correspondence: m.roszczynska@uw.edu.pl
}

Citation: Roszczynska-Kurasinska, M.; Domaradzka, A.; Wnuk, A.; Oleksy, T. Intrinsic Value and Perceived Essentialism of Culture Heritage Sites as Tools for Planning Interventions. Sustainability 2021, 13, 5078. https://doi.org/10.3390/ su13095078

Academic Editors: Luigi Fusco Girard and Marc A. Rosen

Received: 10 February 2021

Accepted: 27 April 2021

Published: 30 April 2021

Publisher's Note: MDPI stays neutral with regard to jurisdictional claims in published maps and institutional affiliations.

Copyright: (c) 2021 by the authors. Licensee MDPI, Basel, Switzerland. This article is an open access article distributed under the terms and conditions of the Creative Commons Attribution (CC BY) license (https:/ / creativecommons.org/licenses/by/ $4.0 /)$.
Abstract: In order to remain alive and relevant, cultural heritage sites have to react and adapt to changing context in a coherent manner, i.e., in a way that is in line with the memory and identity of the place. The incoherent changes, i.e., the transformations that according to the local community do not agree with a character of a place, can be destructive for the long-term vitality of urban cultural heritage. In this study, we test which factors influence social acceptance of different alternations within the context of urban historical gardens that might, in turn, ensure the resilience of the place. Our study focuses on the intangible qualities of the place measured by intrinsic value, perceived essentialism and anti-essentialism as important predictors shaping the response to change. The correlational study was conducted using an online questionnaire designed to empirically grasp intangible qualities of cultural heritage sites. Five hundred twenty-nine responses were included in the analysis. The study shows that perceived historic value, inherent value (uniqueness and importance of the place) and (anti-)essentialist character of a place capture the differences between parks well and enables the finding of interventions that are coherent with a site's genius loci. Measuring intangible qualities of urban gardens can help to design changes that find higher approval among local community members and users of the site. We discuss how the analysis of an intrinsic value and essentialism allows for planning better spatial interventions that align with the human-centered approach to urban development.

Keywords: cultural heritage; intrinsic value; essentialism; essentialist and anti-essentialist place; intervention in park; urban garden

\section{Introduction}

Urban cultural heritage is an expression of the well-established communal ways of life, organized around certain values, customs and places [1], creating a link between the past and the present. Over time, places acquire certain character and functions that often become part of the local identity, stimulate place attachment and are meaningful to local residents [2]. While some of the heritage sites become 'petrified' in their form and function, others remain breeding ground for new activities and innovations. The change in the latter seems to be a natural extension of the existing functions and the physical form of the place. In our research, we wanted to better understand what makes people more open to public space transformation and what qualities of such places deter change.

The social perception of planned interventions in cultural heritage sites depends on the qualities of places [3], communities' and individual preferences, as well as expected effect of the change on the local well-being - some changes boost the livability and happiness of communities in a balanced manner, others influence one aspect of life at the cost of another. Often change requires compromise - a trade-off between adding an attractive function and impairing the 'spirit of the place' [4]. Having this in mind, any transformation in built or natural heritage should take into account a long-term process that led to its current 
meaning and social perception. The trade-off should be commonly agreed upon. Moreover, according to Throsby [5], it should also "ensure equitable participation in the benefits of the heritage among members of the present generation" (p. 50) to warrant the vitality and sustainability of cultural heritage locations.

Historic public parks represent a specific kind of urban cultural heritage, often popular with residents and tourists alike. Unlike many other cultural heritage sites, they serve multiple functions [6], and they undergo a constant change resulting from the alteration of flora to the introduction of new elements like benches, bins, lighting, solar panels or temporary exhibitions. The new elements of infrastructure are often designed to reflect the emerging needs and preferences of space users. However, "the introduction of new elements into historical gardens and parks, both of a functional character ( . . ) as well as of an aesthetic one (...) is still quite controversial." (p. 21) [7]. Łakomy and Sarnat [7] found that "there is a lack of clear guidelines" regarding the shape of the intervention, not even mentioning the need for testing the social acceptance of the planned change. Our study addresses this gap, allowing for more informed decision-making around urban green heritage and, as a result, smoother planning practices. We believe that turning the theoretical concepts of intrinsic value and essence of the place into empirical tools can help to better understand the needs and meanings connected to the place. As such, it has the potential to support local municipalities, investors and heritage communities in matching new events and infrastructure with the character of a given space.

In this study, we examined: (1) What kind of changes are acceptable for a local community in the context of historical green spaces and (2) What factors and qualities of location influence the level of social acceptance for such changes. We focused our study on 'green cultural heritage,' namely the public parks and gardens with cultural value. Studying green spaces allowed us to include a wide range of interventions and innovations that could be introduced in order to satisfy a specific need or upgrade the environmental or cultural function in a given location. The multifunctionality of urban green spaces allowed us to study the relationship between diverse interventions and intangible qualities of urban gardens [6]. On the one hand, parks and gardens have an important recreational value and potential to influence people's health and well-being in a direct way [8-10]. On the other, they often have high aesthetic and historical value and remain monuments rather than accessible breathing spaces. This means that different types of behaviors may be acceptable in one, while completely unsuitable in another location.

\subsection{Intrinsic Value of Cultural Heritage}

One of the important factors in evaluating cultural heritage sites is their intrinsic value [11,12], a concept gaining momentum in recent years but not easily operationalized or quantified. The analysis of existing literature on values of cultural heritage [1,5,13-15] suggests that the measurement of intrinsic value is very much needed to inform the planning processes regarding adaptive reuse of cultural heritage. Intrinsic value reflects the importance of a place to a local community and therefore establishes a frame for human-centered transformation: " (. . ) intrinsic value becomes the foundation of any reuse/regeneration project attentive to the history/tradition/memory and also to the needs of the local community, capable of an authentic propulsive energy, mediating between memory and innovation"(p. 33) [11].It facilitates common meaning-making within the community [16] and reflects the specific identity of places, which in turn generates a complex system of economic, social, environmental and cultural values [14,17].

The notion of intrinsic value, as described in works of Fusco Girard and his colleagues [1,11], allows us to go beyond classical approaches to cultural heritage values. It reflects the importance of place for community, particularly the collectively sustained sentiments attached to and created around it [18]. Tapping into them is a key element of achieving social sustainability of any renovation or re-adaptation plan [16,19]. An introduction of innovative solutions to the cultural heritage sites should ensure their vitality, sustainability and other positive social impacts. The case of Matera [11] shows how notion 
of intrinsic value contributes to understanding why some places radiate energy, generate spontaneous interest and mobilize local communities.

The intrinsic value of cultural heritage sites is produced in the process of collective meaning-making, spanning over time. In other words, it describes the significance of a place for the local community that partially stems from the understanding of the place's function and importance generated by past generations and historical narratives $[13,20]$. The cultural heritage that is a subject of discussion across generations eventually becomes a reference point for a local community. In that way, heritage sites also give the community a feeling of continuity in the constantly changing urban context. The historic value [3,5] of a cultural heritage is, therefore, an important component of the intrinsic value.

While the intrinsic value of a cultural heritage links the community to its past and spans longer than one generation [21], it also has the capacity to enable present or future endeavors, new social and economic practices, as well as other forms of collective action. Intrinsic value emerges from the interactive process in which the social construction of meaning is constantly adjusted and negotiated but also sustained in response to the needs and preferences of the local community. In that way, the common meaning that is incorporated in the intrinsic value of a place has a regenerative potential, as it continues to exist and is being reborn over time.

This regenerative potential can be compared to the auto-poietic capacity of natural resources [1]. Although intrinsic value comes from environmental studies, where species are considered to have "in and for itself" value, the understanding of the intrinsic value in the domain of cultural heritage differs. The value of nature is not conferred by people; therefore, it cannot be revoked by them; it comes from "species' long evolutionary heritage and potential" (p. 731) [22]. The notion of the intrinsic value of cultural heritage does not have exactly the same meaning. Here, the intrinsic value represents a long-lasting connection between social, natural and man-made capitals.

The meaning of cultural heritage is constructed and agreed upon by the members of the community, enacted in the conversations, narratives, stories that are shared, witnessed and retold [23,24]. As a result, its intrinsic value is experienced in a coordinated way by different members of the community and is based on the unique character of a place, not intellectual, but emotional and personal links between a community and a certain building or site. As time passes, the objective reasons for which the place became important to the community can be lost, but what remains is an ongoing sentiment. This means that the place (cultural heritage site) is part of the 'group thought,' 'group mind' or shared reality concepts $[25,26]$. In other words, the intrinsic value of cultural heritage is a result of a group process that allows people to construe, understand and make sense of such places.

The intrinsic value goes beyond physical, aesthetical or morphological analysis of a heritage site. Heritage structures, sites or areas have developed their significance and distinctive character from their meaningful relationships with physical, visual, spiritual and other cultural contexts and settings. Thus, to truly understand and appreciate the substance of the cultural heritage sites and their intangible value, we need a tool for evaluation of the dichotomous character of intrinsic value.

Based on the literature review, we distinguished two components of intrinsic value of cultural heritage: historic value and inherent value. The first component, historic value, captures the historic significance of the place, its ability to conveying past values and meanings through generations. It can be compared to the living memory of a local ecosystem [1]. The second, inherent value, relates to the intangible significance of a place, perceived uniqueness of the place understood as both the quality of a place [20] and the emotional attachment to it. It is the unique combination of physical and spiritual elements that give meaning, value, emotion and mystery to heritage sites [27]. This subjectivity of intrinsic value is something that differentiates it from the perception of intrinsic value in ecological studies, which relates mainly to objective traits $[28,29]$. Unlike nature, cultural heritage is created by people for people, and its value is shaped during a personal encounter with a cultural heritage or discussions over it with other people [30]. 
We posit that knowledge about the significance and perception of local sites should always inform decisions concerning their conservation, management, and, most of all, transformation. Especially when approaching the measurement of social impact, acceptance and sustainability of adaptive reuse, the notion of socially constructed and collectively enacted intrinsic value are crucial [16]. Yet, in the existing literature, intrinsic value and its importance for generating social impacts are described in rather general terms. Understanding the place's intrinsic value and the processes of meaning-making related to it allows us to better embed the renovation projects in the needs and imaginaries of local communities [11] as well as support planning practices of public, private and civil society actors. Applying the described framework should result in better targeted urban transformations and in local residents embracing the change more easily and being more open to experiencing the new or renewed spirit of the place. In our study, we apply the proposed measures of intrinsic value to different urban parks to test if it influences the level of acceptance or rejection of proposed changes within those sites.

\section{2. (Anti-)Essentialism of Place}

Places vary in their openness to change not only from the point of intrinsic value ascribed to them by local communities. Their different qualities make them more or less static or changeable, historic or modern, with a clear identity or in the process of creating one [31]. Classic concepts of place [32,33] emphasize that what defines a place is the specific and stable identity, a kind of a distinct essence of what a place is. Such places are historically continuous, and they usually have clearly defined boundaries, are characterized by immutability, and allow rest and quiescence rather than movement [ibidem].

The identity of a place, as its stable essence, sets limits to what changes to the place are possible without this identity being threatened or destroyed. Previous research on the essentialization of the place showed that opposition to changes in a place perceived as having an immutable essence could be triggered by a perceived lack of fit between these changes and the essence of a given place [34]. That study showed that essentialization was used by the group of residents to defend the identity of the place (the rural setting) and to respond to its potential change (an energy infrastructure implementation). The identity of that place was thus seen as shaped by its unchangeable essence.

Nevertheless, defining place as having a stable essence has been contested, especially by highlighting the oppressive nature of this definition [35-37]. The so-called progressive concept of place stated that a good place is also a place that is changeable, dynamic, its character just being formed, and with no stable identity; thus, such a place may be called anti-essentialist $[38,39]$. Such a place is able to accommodate different narratives and cultural patterns, is by definition more open to change, does not have one true essence, so there is no direct threat to its existing common meaning [36,37].

Previous empirical research has shown that places perceived as essentialist are more meaningful [38] but are also less open to social change or new inhabitants from certain outgroups [39]. As recent studies showed, the preference for essentialist places also leads to a biased assessment of the place's past [40], such as whitewashing of its history or selective memory of its previous characteristics.

Actual living places are difficult to reduce to one-essentialist or anti-essentialist type-however, it is possible to distinguish places that are more essentialist than antiessentialist. The goal of this study was to assess real settings of urban parks in terms of their essentialism and anti-essentialism to test whether essentialist vs. anti-essentialist features of places prevent or facilitate acceptance of potential changes.

We hypothesized that people would be more reluctant to changes in parks perceived as essentialist than anti-essentialist. The type of change was expected to be a significant moderator; therefore, we expected that traditional vs. modern changes should be viewed as more suitable in essentialist places. 


\section{Research Context}

The study was focused on two popular city parks in Warsaw, Poland: the Saxon Garden and the Open Jazdow area (Figure 1). The two parks were chosen because of their similar location (center of Warsaw) and historical importance but were otherwise very different-Saxon Garden has a much more formal and classical character than Open Jazdow.

Saxon Garden is the oldest public park in Warsaw. It was opened to the public in 1727 as a Baroque French formal garden, but one hundred years later, it was reorganized into a Romantic English landscape garden. After the Second World War, it was partially reconstructed. Nowadays, the garden has a rather formal and elegant character: it contains straight symmetrical alleys, rococo sandstone statues, a central fountain, the Tomb of the Unknown Soldier monument and an old building of the Water Tower. Due to its central location, closeness to the Presidential Palace and the National Opera, it remains one of the symbols of Warsaw's past, often visited by tourists and residents.

Open Jazdow is not officially a park but a green oasis in the center of Warsaw, where people often go for a walk. It contains a small settlement of 27 wooden Finnish houses, which were brought to Warsaw from Moscow after the end of the Second World War. The houses were erected as a temporary settlement for the employees of the Warsaw Capital Reconstruction Office. Today, some of the wooden houses together with the surrounding green spaces are open to the public and are managed by a local association. The place is central, yet isolated from the city turmoil, and therefore well suited for relaxation as well as meeting with other people. Open Jazdow promotes itself as the largest grassroots cultural and educational center in Poland.

Taking into account the historical, visual and functional differences between parks, we expected on the one hand that the Saxon Garden would be characterized by a higher historic value and a more essentialist character than Open Jazdow. On the other, we expected that Open Jazdow would be viewed as a more anti-essentialist place with higher inherent value. Our expectations were derived from the observations of a past and current high engagement of the local community in protecting the settlement from demolition [41-43].

Based on the differences in the level of intrinsic value and perceived anti-essentialism of the parks, we anticipated that not all the interventions would be similarly approved in each of the locations. We tested the acceptance of ten different types of interventions that vary in character and meaning. We reckoned that interventions addressing the historic character of the park-historical monument or military song concert-would be more acceptable in the Saxon Garden than in Open Jazdow, as history and tradition are the leitmotiv of the former park. On the same premise, we expected that avant-garde sculpture and electronic music concert would be less acceptable in Saxon Park than in Open Jazdow. On the other hand, the interventions that address the pro-ecological attitudes-rainwater harvesting tank or outdoor exhibition on ecology-would be perceived as more suitable in Open Jazdow, where local associations beside being interested in history are also active in the field of innovation (sustainable development and circularity). Moreover, we expected that interventions regarding eating/drinking and sports-breakfast market, small restaurant/café, outdoor gym-would be equally acceptable in both sites, as parks are often used for recreation, sports and meetings with other people. 


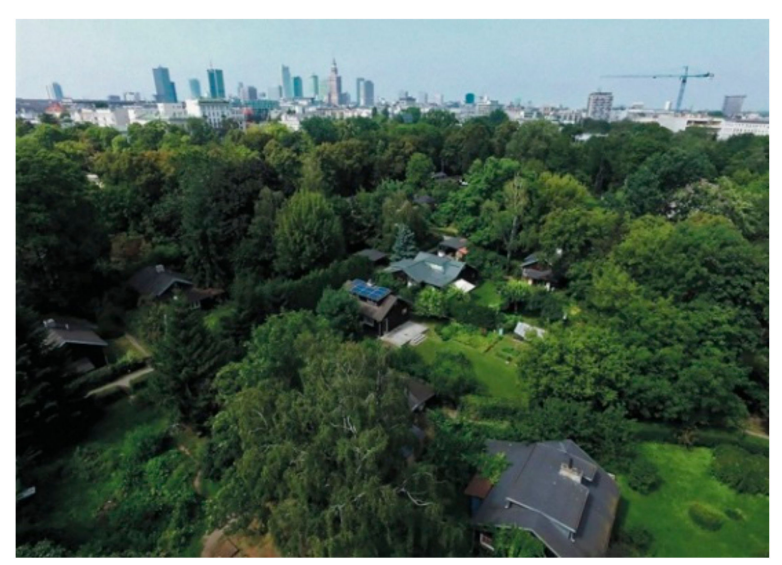

(A)

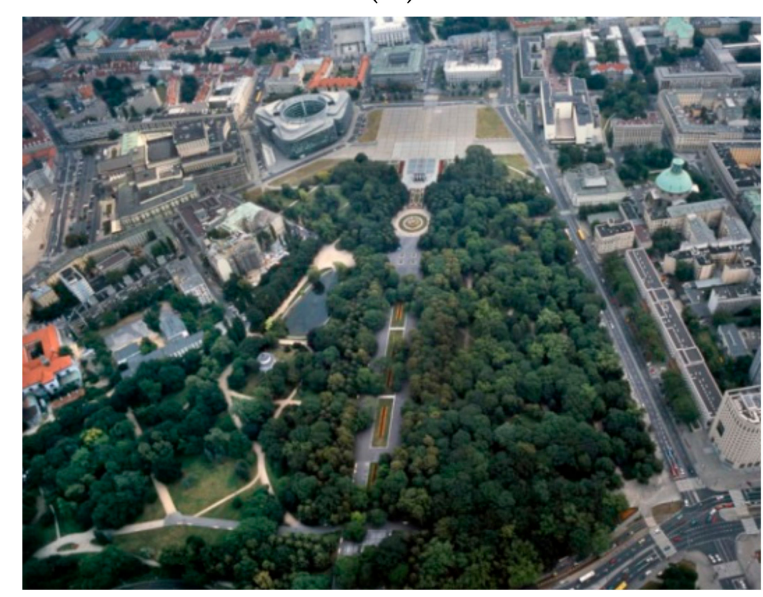

(C)

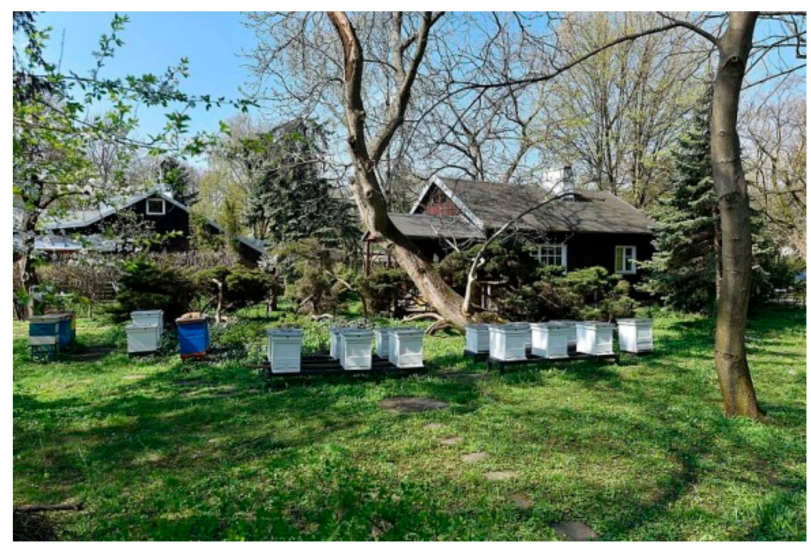

(B)

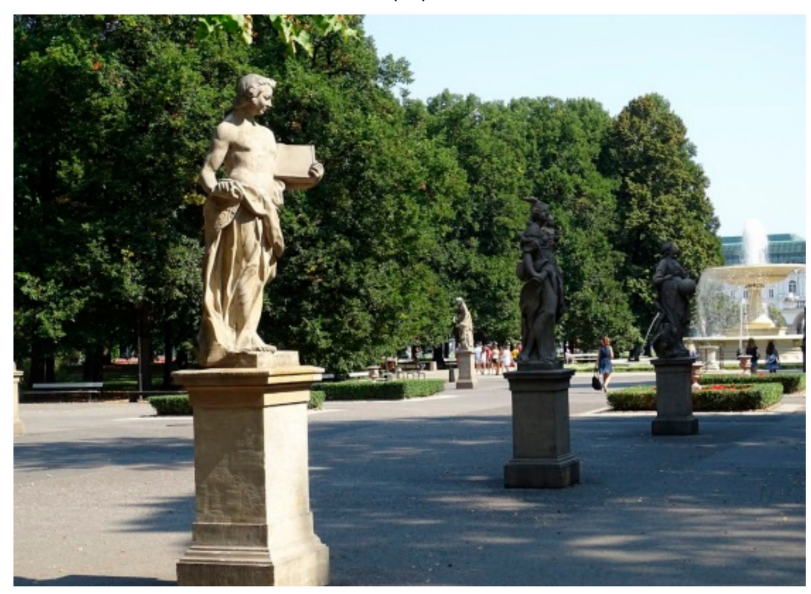

(D)

Figure 1. Photos of two historic parks in Warsaw: (A) Open Jazdow (photo by Mateusz Potempski), (B) Finish wooden houses in Open Jazdow (photo by Adrian Grycuk, CC BY-SA 3.0 PL, via Wikimedia Commons, https://upload.wikimedia. org/wikipedia/commons/0/02/Osiedle_Jazd\%C3\%B3w_domki_fi\%C5\%84skie_miejskie_pszczo\%C5\%82y.jpg, accessed on 16 April 2021) (C) Saxon Garden (photo by Marek Ostrowski) (D) Sculptures in Saxon Garden (photo by Peter Othof, CC BY-ND 2.0, https:/ / www.flickr.com/photos/peterolthof/50175681987, accessed on 16 April 2021).

\section{Materials and Methods}

The online questionnaire was created on the LimeSurvey platform. The link to the study was promoted on Facebook for ten days among adult Facebook users living in Warsaw or commuting within $30 \mathrm{~km}$ from the city center. To incentivize participation in the study, we offered two gift vouchers to participants who would finish the questionnaire (a random drawing procedure was applied). Informed consent was obtained from all participants.

The questionnaire was composed of four sections measuring different aspects of the park, fit of interventions to the character of the park, and finally, a simple demographic of respondents.

We employed a between-subject design and started the study by asking the respondents if they are familiar with one of two parks: Saxon Garden or Open Jazdow. First, we asked about Open Jazdow, a slightly less known place in Warsaw. If a person did not know it, we asked about Saxon Garden.

Once the participants declared that they are familiar with a park, they were redirected to further sections of the questionnaire (see Appendix A), assessing different characteristics of the park and the level of acceptance of different types of intervention.

The character of the park was described by four variables: (1) historic value, (2) inherent value of cultural heritage ( 1 and 2 measure two components of intrinsic value), 
(3) perceived essentialist and (4) anti-essentialist character of a place. The proposed measures were derived from the analysis of literature on intrinsic value and essentialism of places presented in Section 1. The statements used for the operationalization of those dimensions are listed in Table 1 . The respondents were asked to indicate on a scale from 1 to 7 (1-"not at all" and 7-"very much") how much they agree with each of the statements in relation to an urban garden. There were moderate positive correlations between four measures of cultural heritage perception (Table 2).

Table 1. Four dimensions of cultural heritage and their operationalization.

\begin{tabular}{|c|c|c|}
\hline Dimension & Statements & Cronbach's Alpha * \\
\hline Historic value & $\begin{array}{l}\text { This place reminds me of the history of this country. } \\
\text { This place reminds me of the history of the area. }\end{array}$ & 0.69 \\
\hline Inherent value & $\begin{array}{l}\text { This place is special, one of a kind. } \\
\text { No other place can compare to this place. } \\
\text { This place means a lot to me. }\end{array}$ & 0.82 \\
\hline Essentialist character of a place ${ }^{\wedge}$ & $\begin{array}{l}\text { This place has an identity shaped by generations. } \\
\text { This place is unchangeable. } \\
\text { This place is neatly arranged. }\end{array}$ & 0.66 \\
\hline Anti-essentialist character of a place & $\begin{array}{l}\text { The character of this place is constantly being created. } \\
\text { This place captures the spirit of the present day. } \\
\text { This is where different styles and ways of life come together. } \\
\text { This place is modern. }\end{array}$ & 0.80 \\
\hline
\end{tabular}

\footnotetext{
* If a measure was composed of two items, a Pearson correlation was used instead of Cronbach's Alpha. ^ The original version of the essentialist character of place measure was composed of four items, but the principal component analysis run on eight items questionnaire revealed that one item, "This place has a unique atmosphere," cross-loaded on both components. The minimal difference of 0.3 between loadings has not been reached, and therefore, the item was removed from the scale.
}

Table 2. Person correlations for inherent value, historic value, essentialist and anti-essentialist character of the place.

\begin{tabular}{cccc}
\hline & Historic Value & Inherent Value & Essentialist Character of a Place \\
\hline Inherent value & $0.569^{* *}$ & & \\
Essentialist character of a place & $0.521^{* *}$ & $0.518^{* *}$ & $0.299^{* *}$ \\
Anti-essentialist character of a place & $0.462^{* *}$ & $0.462^{* *}$ & \\
\hline
\end{tabular}

** statistically significant at $p<0.01$ level.

The dependent variable of the study - the fit of an intervention to the character of the park - was assessed by respondents on a scale from 1 to 7 (1 indicating "not at all" and 7 indicating "very much"). We tested ten different interventions that could be implemented in the park: a breakfast market, small restaurant/cafe, outdoor gym, electronic music concert, military song concert, an outdoor exhibition on ecology, avant-garde sculpture, historical monument, rainwater tank and a political rally. Half of the interventions had a rather permanent character (e.g., small restaurant/café), while the other half would only have a temporary effect on the park (e.g., concert). The planned interventions were diversified in terms of their character; some referred to the traditional values (historic monument), others to hedonistic values (breakfast market, outdoor gym), as well as environmental consciousness (rainwater tank, exhibition) and the expression of emotions and opinions (political rally).

At the end of the questionnaire, we asked participants to indicate their gender, age, level of education and place of living.

\section{Analytical Strategy}

We conducted our analysis in four steps. First, we measured whether there were differences in intangible character between parks using independent-sample t-tests. The following independent variables were included in the analysis: historic value of a garden, the inherent value of a garden, essentialist and anti-essentialist character of a place. 
Secondly, we assessed which interventions would be more acceptable in which park. We tested the 'suitability of the intervention' to the given park, using a multivariate analysis of variance (MANOVA).

Thirdly, we explored whether there were similarities between interventions by running a principal component analysis. The aim of this analysis was to form groups (components) of similar interventions and use these groups in further analysis.

Fourthly, we tested our hypotheses regarding the relationship between the intangible character of the park and the level of suitability of different interventions using path analysis conducted in Mplus [44]. In Model 1, we included two types of intrinsic value (historic value and inherent value) and perceived essentialist and anti-essentialist character of a place as predictors, and three types of possible changes in parks as dependent variables. In Model 2, we added covariates (gender, age, frequency of using the park) to test whether the effect of the main predictors still held. We conducted the analyses with robust maximum likelihood estimation (MLR) to account for non-normally distributed data. We also used the full information maximum likelihood procedure (FIML) to deal with missing values where appropriate.

\section{Results}

\subsection{Respondents}

Out of 842 persons who started the survey, 529 persons completed at least the first section of the questionnaire and were included in the analysis. Participants who did not know any of the mentioned parks were excluded from the study. In total, 403 persons (51\% women) aged 18-77 ( $\mathrm{M}=48.37, \mathrm{SD}=14.38)$ fully completed the questionnaire. The majority of respondents who completed the questionnaire lived in Warsaw $(91.8 \%)$ and had a higher education level (78.8\%).

\subsection{Differences between Parks}

We run a series of four independent-samples t-tests to determine if there were differences in assessment of historic value, inherent value, essentialist, and anti-essentialist between parks. The historic value was higher for Saxon Garden $(\mathrm{M}=4.93, \mathrm{SD}=1.72)$ than for Open Jazdow $(M=4.61, S D=1.7)$, a statistically significant difference, $M=-0.32,95 \%$ $\mathrm{CI}[-0.61,-0.03], \mathrm{t}(527)=-2.17, p=0.03$. The same results were obtained for essentialist character of the place. The Saxon Garden was perceived as more essentialist $(\mathrm{M}=4.7$, $\mathrm{SD}=1.24)$ than Open Jazdow $(\mathrm{M}=4.35, \mathrm{SD}=1.26)$, a statistically significant difference, $\mathrm{M}=-0.36,95 \%$ CI $[-0.58,-0.13], \mathrm{t}(467)=-3.09, p=0.002$.

On the other hand, the inherent value was lower for Saxon Garden $(\mathrm{M}=3.71, \mathrm{SD}=1.49)$ than for Open Jazdow $(\mathrm{M}=4.18, \mathrm{SD}=1.63)$, a statistically significant difference, $\mathrm{M}=0.46$, $95 \%$ CI $[0.2,0.73], t(527)=3.4, p=0.001$, and the Saxon Garden was perceived as less anti-essentialist $(\mathrm{M}=3.48, \mathrm{SD}=1.24)$ than Open Jazdow $(\mathrm{M}=4.36, \mathrm{SD}=1.31)$, a statistically significant difference, $\mathrm{M}=0.87,95 \% \mathrm{CI}[0.64,1.1], \mathrm{t}(466)=7.37, p<0.001$.

\subsection{Fit of Interventions to the Park}

We ran a one-way multivariate analysis of variance (MANOVA) to determine which interventions would be judged as more suitable to which park (Table 3). There was a statistically significant difference between the parks on a combination of ten interventions, $\mathrm{F}(10,400)=23.27, p<0.005$; Wilks' lambda $=0.63$; partial $\eta 2=0.37$. The univariate effect of the park was significant in the case of nine interventions. Six out of ten interventionsbreakfast market, outdoor gym, electronic music concert, an outdoor exhibition on ecology, avant-garde sculpture, rainwater tank-were more acceptable in Open Jazdow than Saxon Garden. Only a military song concert, a historic monument and political rally were seen as more acceptable interventions in the Saxon Garden. Small restaurant/café was equally acceptable in both parks. 
Table 3. Results of one-way multivariate analysis of variance examining the differences in acceptability of interventions between parks.

\begin{tabular}{|c|c|c|c|c|c|c|c|}
\hline & \multicolumn{2}{|c|}{ Open Jazdow } & \multicolumn{2}{|c|}{ Saxon Garden } & \multirow[t]{2}{*}{$\mathbf{F}$} & \multirow[t]{2}{*}{ df } & \multirow[t]{2}{*}{$p$} \\
\hline & $\mathbf{M}$ & SD & $\mathbf{M}$ & SD & & & \\
\hline Breakfast market & 4.55 & 2.04 & 3.37 & 1.96 & 35.60 & 1,409 & $<0.001$ \\
\hline Small restaurant/café & 5.21 & 1.87 & 4.93 & 1.92 & 2.25 & 1,409 & 0.13 \\
\hline Outdoor gym & 3.62 & 2.05 & 2.97 & 1.89 & 10.93 & 1,409 & 0.001 \\
\hline Electronic music concert & 2.99 & 2.07 & 2.42 & 1.69 & 9.35 & 1,409 & 0.002 \\
\hline Military song concert & 2.02 & 1.58 & 3.59 & 2.01 & 78.06 & 1,409 & $<0.001$ \\
\hline Outdoor exhibition on ecology & 5.58 & 1.7 & 4.71 & 1.87 & 24.45 & 1,409 & $<0.001$ \\
\hline Avant-garde sculpture & 4.90 & 1.99 & 3.49 & 2.11 & 48.88 & 1,409 & $<0.001$ \\
\hline Historical monument & 3.38 & 2.04 & 4.68 & 2.1 & 40.63 & 1,409 & $<0.001$ \\
\hline Rainwater tank & 5.43 & 1.89 & 4.00 & 2.12 & 52.52 & 1,409 & $<0.001$ \\
\hline Political rally & 1.80 & 1.46 & 2.15 & 1.71 & 4.83 & 1,409 & 0.03 \\
\hline
\end{tabular}

\subsection{Grouping of Interventions}

In order to group the interventions thematically, we run a principal components analysis (PCA) on all 10 interventions. The suitability of PCA was assessed prior to the analysis. The overall Kaiser-Meyer-Olkin (KMO) measure was 0.73 , with individual KMO measures all greater than 0.5 . Bartlett's Test of Sphericity was statistically significant $(p<0.0005)$, indicating that the data was likely factorizable.

PCA revealed three components that had eigenvalues greater than one, and which explained $30.83 \%, 16.79 \%$ and $10.03 \%$ of the total variance, respectively.

The three-component solution explained $57.65 \%$ of the total variance. A Varimax orthogonal rotation was employed. Component loadings of the rotated solution are presented in Table 4.

The first component was formed by five variables: breakfast market, small restaurant, outdoor gym, an outdoor exhibition on ecology and rainwater tank. The second component was built by two variables: military song concert and historical monument. The third component comprised two variables: electronic music concert and political rally. The avantgarde sculpture was excluded from further analysis as the item loaded equally strong on component 1 and 3 .

Table 4. Rotated Structure Matrix for PCA with Varimax Rotation.

\begin{tabular}{lccc}
\hline & \multicolumn{3}{c}{ Rotated Component Coefficients } \\
\cline { 2 - 4 } Items & Component 1 & Component 2 & Component 3 \\
\hline Breakfast market & $\mathbf{0 . 6 5 5}$ & 0.067 & 0.272 \\
Small restaurant/cafe & $\mathbf{0 . 6 3 4}$ & 0.207 & 0.096 \\
Outdoor gym & $\mathbf{0 . 6 4 6}$ & 0.065 & 0.071 \\
Electronic music concert & 0.262 & -0.013 & $\mathbf{0 . 7 9 2}$ \\
Military song concert & -0.014 & $\mathbf{0 . 8 2 9}$ & 0.131 \\
Outdoor exhibition on ecology & $\mathbf{0 . 7 6 0}$ & 0.005 & 0.047 \\
Avant-garde sculpture & 0.502 & -0.145 & 0.536 \\
Historical monument & 0.176 & $\mathbf{0 . 8 0 3}$ & -0.126 \\
Rainwater tank & $\mathbf{0 . 6 9 6}$ & -0.100 & 0.091 \\
Political rally & -0.110 & 0.511 & $\mathbf{0 . 6 0 7}$ \\
\hline
\end{tabular}

Note. Major loadings for each item are marked in bold.

Inspection of the Table 4 reveals that component 1 represents pro-health interventions. The interventions that form this component address the basic needs of the body, like nutrition, sports activity and a healthy environment. Component 2 represents pro-tradition changes and group interventions that recall the past and historical events. Component 3 represents the initiatives that encourage the collective self-expression of emotions or opinions. 


\subsection{Path Analyses}

The results of the path analysis showed that positive attitudes towards changes related to health and changes encouraging collective self-expression were significantly predicted only by the anti-essentialist character of the park (see Tables 5 and 6).

Table 5. The effect of intrinsic values and (anti-)essentialist character of a place on acceptance of pro-health interventions in parks.

\begin{tabular}{ccccc}
\hline Pro-Health Interventions & \multicolumn{2}{c}{ Model 1 } & \multicolumn{2}{c}{ Model 2 } \\
\hline Intercept & $\beta$ & SE & $\beta$ & SE \\
Inherent value & $1.79 * *$ & 0.23 & $1.94^{*}$ & 0.30 \\
Historical value & 0.01 & 0.06 & 0.03 & 0.06 \\
Essentialist character of a place & 0.04 & 0.06 & 0.01 & 0.05 \\
Anti-essentialist character of a place & -0.05 & 0.06 & -0.04 & 0.06 \\
Age & $0.49^{* *}$ & 0.05 & $0.48^{* *}$ & 0.05 \\
Gender & & & -0.07 & 0.04 \\
Frequency of using the park & \multicolumn{3}{c}{$0.11^{*}$} & 0.04 \\
R2 & \multicolumn{3}{c}{0.25} \\
\hline
\end{tabular}

Note: Standardized estimates are presented. ${ }^{*} p<0.05,{ }^{* *} p<0.01$.

Table 6. The effect of intrinsic values and (anti-)essentialist character of a place on acceptance of interventions encouraging collective self-expression in parks.

\begin{tabular}{ccccc}
\hline $\begin{array}{c}\text { Collective Self-Expression } \\
\text { Interventions }\end{array}$ & \multicolumn{2}{c}{ Model 1 } & \multicolumn{2}{c}{ Model 2 } \\
\hline Intercept & B & SE & $\beta$ & SE \\
\hline Inherent value & $1.14^{* *}$ & 0.24 & $1.66^{*}$ & 0.29 \\
Historical value & -0.03 & 0.06 & -0.01 & 0.06 \\
Essentialist character of a place & -0.10 & 0.06 & -0.11 & 0.06 \\
Anti-essentialist character of a place & 0.02 & 0.06 & 0.05 & 0.06 \\
Age & $0.29^{* *}$ & 0.05 & $0.29^{* *}$ & 0.05 \\
Sex & & & $-0.14^{* *}$ & 0.05 \\
Frequency of using the park & & & -0.01 & 0.05 \\
R2 & \multicolumn{2}{c}{0.07} & -0.06 & 0.05 \\
\hline
\end{tabular}

Note: Standardized estimates are presented. ${ }^{*} p<0.05,{ }^{* *} p<0.01$.

Pro-tradition interventions were positively predicted by both the historical intrinsic value and essentialist character of the park, while the intrinsic value related to the perception of the inherent value of the place was negatively associated with attitude towards pro-tradition interventions (see Table 7). The results did not change when covariates were included. 
Table 7. The effect of intrinsic values and (anti-)essentialist character of a place on acceptance of pro-tradition interventions in parks.

\begin{tabular}{ccccc}
\hline Pro-Tradition Interventions & \multicolumn{2}{c}{ Model 1 } & \multicolumn{2}{c}{ Model 2 } \\
\hline Intercept & $\boldsymbol{\beta}$ & SE & $\boldsymbol{\beta}$ & SE \\
\hline Inherent value & $1.23^{* *}$ & 0.22 & $1.25^{*}$ & 0.29 \\
Historical value & $-0.19^{* *}$ & 0.06 & $-0.19^{* *}$ & 0.04 \\
Essentialist character of a place & $0.31^{* *}$ & 0.06 & $0.31^{* *}$ & 0.04 \\
Anti-essentialist character of a place & $0.13^{*}$ & 0.06 & $0.14^{*}$ & 0.04 \\
Age & -0.06 & 0.06 & -0.07 & 0.04 \\
Sex & & & -0.06 & 0.03 \\
Frequency of using the park & \multicolumn{3}{c}{0.10} \\
R2 & & & 0.07 & 0.03 \\
\hline Note: Standardized estimates are presented. ${ }^{*} p<0.05,{ }^{* *} p<0.01$. \\
\end{tabular}

\section{Discussion}

The main objective of the presented study was to explore ways of measuring intangible qualities of heritage public parks to support the process of planning the interventions in a way that ensures higher social approval. Based on the existing literature, we proposed and tested a new empirical tool to measure the intangible qualities of the heritage sites. We focused on two qualities of cultural heritage: intrinsic value as a combination of historic value and uniqueness that evokes attachment [1,11], as well as perceived (anti-)essentialism [38].

The results show that studied parks differ from each other at all four dimensions as expected. The Saxon Garden has a higher historic value and is perceived as a more essentialist place in comparison to Open Jazdow. Meanwhile, the Open Jazdow is assessed as a place with higher inherent value, slightly more anti-essentialist character and as a place that undergoes changes. Although the meaning of the Open Jazdow has not been well established yet, people feel that this place is unique and one of its kind. The visitors of Open Jazdow formed a special bond with Open Jazdow, which is stronger than the one formed by visitors of the Saxon Garden. This shows that not only essentialist places may be associated with unique atmosphere and emotional attachment, as seen in other studies [38]. Nevertheless, this effect may be specific to natural places, while previous research showed that, in the case of human-made sites, the essentialist places are related to higher meaningfulness and place attachment $[34,38]$.

We expected that the perception of the park, and specifically the perception of its intangible value, would affect the evaluation of the suitability of the possible intervention to the park. We tested ten different interventions that could fit into the multifunctional character of the park [6], like leisure, sport, or culture. Results of the data analysis revealed that all the interventions except one - a small restaurant/café - were accepted at different levels in both urban gardens. Military song concerts, historical monument and political rally were judged as better fit to more formal and traditional Saxon Garden than Open Jazdow. While interventions related to building healthy environment (an outdoor exhibition on ecology, rainwater tank), sport (outdoor gym), relaxation and meetings with other people (avant-garde sculpture, breakfast market, electronic music concert) were evaluated as better fit to Open Jazdow, a more anti-essentialist and more unique place (in terms of inherent value) than Saxon Garden. Results confirm our expectation that finding a right location for any intervention, even a temporal one like breakfast market, should take into account differences in intangible qualities of urban gardens. Even interventions that fit a general function of park, like relaxation, can be less welcomed in one urban garden than other.

In the consecutive step, we found that differences in the perceived fit of interventions to urban garden can be well explained by the intangible character of that garden: its historic value, inherent value (subjective uniqueness of a place), perceived essentialist or anti-essentialist character of a place. Before the exploration of the above relation, the tested 
interventions were grouped into three sets: interventions that affect health (connected with nutrition, sport and environment), ones that allow self-expression as part of the collective activity (political rally, electronic music concert), and ones that enable contemplation of the past (historical monument and military song concert).

We found that the acceptance of pro-tradition interventions was positively predicted by the essentialist character of a park, historic value of a place and negatively predicted by inherent value of a garden. This is in line with literature emphasizing that the identity of essentialist places is built upon tradition and historical continuity. Thus, pro-tradition interventions are more acceptable as they are less prone to change the stable essence of a place and its historic value. In turn, changes that do not fit the well-established essence of the place may be less welcome. Interestingly, the perceived uniqueness of the place and its subjective importance (inherent value) was not conductive to accepting pro-tradition interventions.

According to our hypotheses, more novel and innovative changes, such as pro-health and collective self-expression interventions were related to the anti-essentialist character of the place. An anti-essentialist, dynamic place, in which identity is constantly being recreated, is thus open for changes that are also dynamic and modern. This outcome contributes research by Wnuk et al. [39], showing that anti-essentialist places entail more ethnic diversity than essentialist ones. There was no significant relationship between the anti-essentialist character of a place and the suitability of pro-tradition interventions, which suggests that these kind of changes are perceived as neutral to anti-essentialist places. Our results extend previous research on place essentialism into a novel area: attitudes toward spatial changes, either consistent or inconsistent with the character of place. The results may have a wide range of implications for city governments, planners and others interested in place-making and revitalization.

Our analysis shows that the notion of intrinsic value can be turned into a specific variable that measures and explains different preferences and visions concerning site development. Moreover, we add the concept of the essentialist and anti-essentialist character of a place to the valorization model to underline some specific characteristics of cultural heritage sites that make them more or less open to changes. The proposed tool allows for a better understanding of people and places and, most importantly, the place-related needs and preferences among residents. By adopting those new measures in a planning phase, we hope that the risk of failed, mismatched investments within cultural heritage sites can be minimized [45]. In the long run, this approach could help to implement humancentered urban policies [46] and avoid the destruction of the genius loci of many cultural heritage sites.

We strongly believe that changes within historic and socially meaningful places can be enriching, as long as we make sure to understand the different aspects of the site's intangible value. While much has been said about the importance of preserving the 'spirit of the place,' we tried to make this notion more concrete and empirically tangible.

This paper complements research on people-driven planning of the interventions within cultural heritage sites, using the example of green spaces of special historic and social value. On the one hand, the survey results demonstrated new tools for measuring the intangible value of cultural heritage sites. On the other hand, they showed opportunities to better match investments with users' preferences and local communities' needs. With this paper, we also hope to contribute to the development of a more comprehensive valorization system of the cultural heritage and landscape.

\section{Limitations}

Due to the COVID-19 pandemic, we had to conduct our study online among Facebook users, which might limit the generalizability of the obtained results. All participants were adults, and the majority of them had higher education, which might not be fully representative of the population of users of Warsaw's urban gardens. The future study should be conducted on-site, which would allow for collecting answers from a more diverse 
group of respondents, as well as further testing our approach in different types of green areas and cultural heritage sites.

The other important limitation of the study is the lack of proper control of respondents personal preferences regarding interventions. The respondent's attitude toward historical events or pro-ecological solutions might affect the judgment about the suitability of these interventions. The future study should be complemented by including the proper control of such preferences, although we reckon that adding these preferences to the model would not change the relations between predictors and dependent variables.

The results of our study should be also replicated in the context of built heritage to make sure that the measures of characteristics of green spaces can be extrapolated to other heritage sites.

Author Contributions: Conceptualization, M.R.-K., A.W., A.D. and T.O.; methodology, M.R.-K., A.W. and T.O.; investigation, M.R.-K. and A.W.; data curation and analysis, M.R.-K. and A.W.; writingoriginal draft preparation, M.R.-K., A.W., A.D. and T.O.; writing-review and editing, M.R.-K., A.W. and A.D.; funding acquisition, A.D. and A.W. All authors have read and agreed to the published version of the manuscript.

Funding: This research was funded by European Commission [Grant Agreement number: 776758]. The work of Anna Wnuk and Tomasz Oleksy was funded by the National Science Centre [Grant Agreement number: 2017/25/B/HS6/00137].

Institutional Review Board Statement: The study was conducted according to the guidelines of the Declaration of Helsinki, and approved by the Research Ethics Committee at the Robert Zajonc Institute for Social Studies, University of Warsaw.

Informed Consent Statement: Informed consent was obtained from all subjects involved in the study.

Data Availability Statement: The data that supports the findings of this study are available from the corresponding author upon reasonable request.

Conflicts of Interest: The authors declare no conflict of interest. The funders had no role in the design of the study; in the collection, analyses, or interpretation of data; in the writing of the manuscript, or in the decision to publish the results. 


\section{Appendix A}

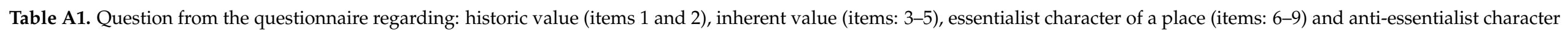
of a place (items: 10-13).Respondents were asked to mark on a scale from 1 to 7 how much they agreed with the following description of the park.

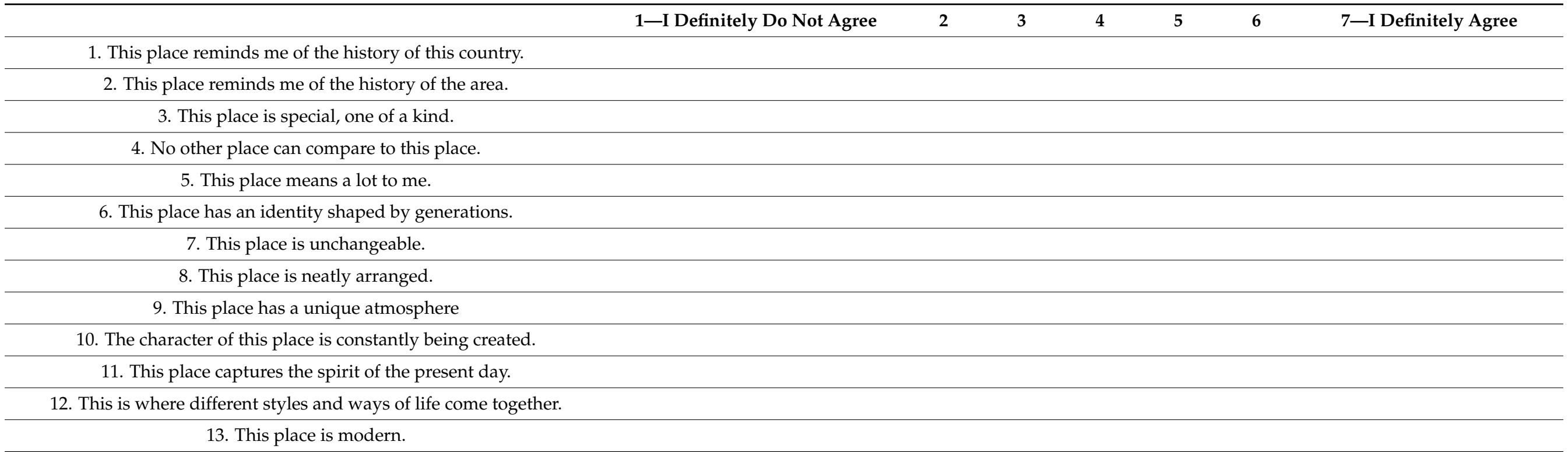


Table A2. Question from the questionnaire regrading interventions. Respondents were asked toread a list of potential initiatives that may be implemented in the park and to mark how well each intervention fits the nature of the park.

\begin{tabular}{ccllllll}
\hline & $\begin{array}{c}\text { 1-It Definitely Does } \\
\text { Not Fit }\end{array}$ & 2 & 3 & 4 & 5 & 6 & 7 -It Definitely Fits \\
\hline Breakfast market & & \\
\hline Small restaurant/café & \\
\hline Outdoor gym \\
\hline Electronic music concert \\
\hline Military song concert \\
\hline $\begin{array}{c}\text { Outdoor exhibition } \\
\text { on ecology }\end{array}$ \\
\hline Avant-garde sculpture \\
\hline Historical monument \\
\hline Rainwater tank \\
\hline Political rally \\
\hline
\end{tabular}

\section{References}

1. Fusco Girard, L.; Vecco, M. The "Intrinsic Value" of Cultural Heritage as Driver for Circular Human-Centered Adaptive Reuse. Sustainability 2021, 13, 3231. [CrossRef]

2. Lewicka, M. Place Attachment, Place Identity, and Place Memory: Restoring the Forgotten City Past. J. Environ. Psychol. 2008, 28, 209-231. [CrossRef]

3. Murzyn-Kupisz, M. Barbarzyńca w Ogrodzie? Dziedzictwo Kulturowe Widziane z Perspektywy Ekonomii. Zarzadzanie Publiczne 2010, 13, 19-32.

4. Bottero, M.; D'Alpaos, C.; Oppio, A. Ranking of Adaptive Reuse Strategies for Abandoned Industrial Heritage in Vulnerable Contexts: A Multiple Criteria Decision Aiding Approach. Sustainability 2019, 11, 785. [CrossRef]

5. Throsby, D. Heritage Economics: A Conceptual Framework. Econ. Uniqueness 2012, 45, 45-74.

6. Gullino, P.; Pomatto, E.; Gaino, W.; Devecchi, M.; Larcher, F. New Challenges for Historic Gardens' Restoration: A Holistic Approach for the Royal Park of Moncalieri Castle (Turin Metropolitan Area, Italy). Sustainability 2020, 12, 10067. [CrossRef]

7. Łakomy, K.; Sarnat, L. Contemporary Art in the Historic Landscape. Czas. Tech. 2017, 2017, 15-22.

8. Maller, C.; Townsend, M.; St Leger, L.; Henderson-Wilson, C.; Pryor, A.; Prosser, L.; Moore, M. Healthy Parks, Healthy People: The Health Benefits of Contact with Nature in a Park Context. In The George Wright Forum; George Wright Society: Hancock, MI, USA, 2009; Volume 26, pp. 51-83.

9. Payne, L.L.; Orsega-Smith, E.; Roy, M.; Godbey, G.C. Local Park Use and Personal Health among Older Adults: An Exploratory Study. J. Park Recreat. Adm. 2005, 23, 1-20.

10. Orsega-Smith, E.; Mowen, A.J.; Payne, L.L.; Godbey, G. The Interaction of Stress and Park Use on Psycho-Physiological Health in Older Adults. J. Leis. Res. 2004, 36, 232-256. [CrossRef]

11. Girard, L.F.; Nocca, F.; Gravagnuolo, A. Matera: City of Nature, City of Culture, City of Regeneration. Towards a Landscape-Based and Culture-Based Urban Circular Economy. Aestimum 2019, 74, 5-42.

12. Gravagnuolo, A.; Saleh, R.; Ost, C.; Fusco Girard, L. Towards an Evaluation Framework to Assess Cultural Heritage Adaptive Reuse Impacts in the Perspective of the Circular Economy. Urban. Inf. 2018, 28-31. [CrossRef]

13. Francis-Lindsay, J. The Intrinsic Value of Cultural Heritage and Its Relationship to Sustainable Tourism Development: The Contrasting Experiences of Jamaica and Japan. Caribb. Q. 2009, 55, 151-168. [CrossRef]

14. Vecco, M. Value and Values of Cultural Heritage. In Cultural Heritage; Routledge: London, UK, 2018 ; p. 23.

15. Labadi, S. UNESCO, Cultural Heritage, and Outstanding Universal Value: Value-Based Analyses of the World Heritage and Intangible Cultural Heritage Conventions; Rowman \& Littlefield: Lanham, MD, USA, 2013.

16. Roszczynska-Kurasinska, M.; Domaradzka, A.; Ślosarski, B.; Żbikowska, A. Embracing Circularity in Adaptive Reuse-Grassroots Perspective. In STS Conference Graz 2019. Critical Issues in Science, Technology and Society Studies; Verlag der Technischen Universität Graz: Graz, Austria, 2019; pp. 363-383.

17. CHCFE Consortium Cultural Heritage Counts for Europe Full Report; Europa Nostra: Brussels, Belgium, 2015.

18. Klamer, A. The values of cultural heritage. In Handbook on the economics of cultural heritage; Edward Elgar Publishing: Cheltenham, UK, 2013. 
19. Missimer, M.; Robèrt, K.-H.; Broman, G. A Strategic Approach to Social Sustainability-Part 1: Exploring the Social System. J. Clean. Prod. 2017, 140, 32-41. [CrossRef]

20. Vecco, M. Genius Loci as a Meta-Concept. J. Cult. Herit. 2020, 41, 225-231. [CrossRef]

21. Rojas, E. Governance in Historic City Core Regeneration Projects. In The Economics of Uniqueness; The World Bank: Washington, DC, USA, 2012; p. 143.

22. Soulé, M.E. What Is Conservation Biology? BioScience 1985, 35, 727-734.

23. Higgins, E.T. Achieving'shared Reality'in the Communication Game: A Social Action That Create; Meaning. J. Lang. Soc. Psychol. 1992, 11, 107-131. [CrossRef]

24. Bourdieu, P. Distinction: A Social Critique of the Judgement of Taste; Harvard University Press: Cambridge, MA, USA, 1984.

25. Hardin, C.D.; Higgins, E.T. Shared Reality: How Social Verification Makes the Subjective Objective. In Handbook of Motivation and Cognition; The Guilford Press: New York, NY, USA, 1996.

26. Higgins, E.T. Shared Reality: What Makes Us Strong and Tears Us Apart; Oxford University Press: Oxford, UK, 2019.

27. ICOMOS Quebec Declaration on the Preservation of Spirit of Place 2008. Available online: https://whc.unesco.org/uploads/ activities/documents/activity-646-2.pdf (accessed on 20 April 2021).

28. Elliot, R. Intrinsic Value, Environmental Obligation and Naturalness. Monist 1992, 75, 138-160. [CrossRef]

29. Rea, A.W.; Munns, W.R. The Value of Nature: Economic, Intrinsic, or Both? Integr. Environ. Assess. Manag. 2017, 13, 953-955. [CrossRef] [PubMed]

30. Framarin, C.G. Hinduism and Environmental Ethics: An Analysis and Defense of a Basic Assumption. Asian Philos. 2012, 22, 75-91. [CrossRef]

31. Cresswell, T. Place: A Short Introduction; Blackwell Publishing: Hoboken, NJ, USA, 2004.

32. Tuan, Y.-F. Space and Place: The Perspective of Experience; U of Minnesota Press: Minneapolis, MN, USA, 1977.

33. Relph, E. Place and Placelessness; Pion: London, UK, 1976.

34. Batel, S.; Devine-Wright, P.; Wold, L.; Egeland, H.; Jacobsen, G.; Aas, O. The Role of (de-) Essentialisation within Siting Conflicts: An Interdisciplinary Approach. J. Environ. Psychol. 2015, 44, 149-159. [CrossRef]

35. De Certeau, M.D. The Practice of Everyday Life; University of California Press: Berkeley, CA, USA, 2011.

36. Harvey, D.J.; Merry, A.H.; Royle, L.; Campbell, M.P.; Rudd, P.M. Justice, Nature E the Geography of Difference; Blackwell: Oxford, UK, 1996.

37. Massey, D. A Global Sense of Place. Marx. Today 1991, 38, 24-29.

38. Lewicka, M.; Rowiński, K.; Iwańczak, B.; Bałaj, B.; Kula, A.M.; Oleksy, T.; Prusik, M.; Toruńczyk-Ruiz, S.; Wnuk, A. On the Essentialism of Places: Between Conservative and Progressive Meanings. J. Environ. Psychol. 2019, 65, 101318. [CrossRef]

39. Wnuk, A.; Oleksy, T.; Toruńczyk-Ruiz, S.; Lewicka, M. The Way We Perceive a Place Implies Who Can Live There: Essentialisation of Place and Attitudes towards Diversity. J. Environ. Psychol. 2021, 75, 101600. [CrossRef]

40. Wnuk, A.; Oleksy, T.; Toruńczyk-Ruiz, S. A Cognitively-Gated Place? The Role of Need for Closure in a Biased Perception of the Place's Past. Curr. Psychol. 2019, 1-12. [CrossRef]

41. Piekutowski, J. Osiedle Jazdów: Sen o Społecznościowym Zarządzaniu. Więź 2018, 61, 37-41.

42. Zielińska, E. Polifoniczna Praktyka Przestrzenna. O Koszmarze Partycypacji Markusa Miessena. Soc. Commun. 2015, 321-334. [CrossRef]

43. Hołuj, D. Podejście Partycypacyjne w Kształltowaniu Przestrzeni Centralnych Miasta. Przykład Osiedla Domków Fińskich w Warszawie. Studia Miej. 2017, 28, 99-119. [CrossRef]

44. Muthén, L.K.; Muthén, B.O. Mplus Version 7 User's Guide; Muthén \& Muthén: Los Angeles, CA, USA, 2012.

45. Domaradzka, A. The Un-Equal Playground: Developers and Urban Activists Struggling for the Right to the City. Geoforum 2019. [CrossRef]

46. The Human-Centred City. Opportunities for Citizens through Research and Innovation: A Public Summary; Publications Office of the EU: Luxembourg, 2019. 